University of Miami Law School University of Miami School of Law Institutional Repository

1994

\title{
The Future of the United Nations Convention on the Law of the Sea
}

John R. Stevenson

Bernard H. Oxman

University of Miami School of Law, bhoxman@law.miami.edu

Follow this and additional works at: https://repository.law.miami.edu/fac_articles

Part of the Law of the Sea Commons

\section{Recommended Citation}

John R. Stevenson and Bernard H. Oxman, The Future of the United Nations Convention on the Law of the Sea, 88 Am. Jl. Int'l. Law 488 (1994).

This Article is brought to you for free and open access by the Faculty and Deans at University of Miami School of Law Institutional Repository. It has been accepted for inclusion in Articles by an authorized administrator of University of Miami School of Law Institutional Repository. For more information, please contact library@law.miami.edu. 
And of course the rules to be administered through the GATT/WTO dispute settlement system are far from perfect, but reflect a series of compromises, tradeoffs and bargains that often make it difficult to detect the principle behind a given rule. Still, the system here described looks promising, sufficiently promising to justify the decisions of the United States and other countries in the final frantic days of the Uruguay Round to yield on matters on which they had said they would never yield-grain exports, rice imports, taxes on movies, textile quotas or whatever.

I have never believed that a right without a remedy is no right at all. But there can be no doubt that the closer a legal system comes to affording remedies for breaches of rules, the stronger are the rights it confers, and the more reliance can be placed on the rules. The Understanding on Dispute Settlement and creation of the WTO are as yet untested, but they appear to be major steps in the right direction.

ANDREAS F. LOWENFELD

\section{The Future of the UnIted Nations Convention ON THE LAW OF THE SEA}

After fifteen years of continuous, intense and difficult negotiations among the nations of the world, the United Nations Convention on the Law of the Sea was adopted in $1982 .{ }^{1}$ The overwhelming majority of states signed it and over sixty have ratified it. ${ }^{2}$ It will enter into force on November 16, 1994.

Now the world must decide whether or not the Convention will be widely ratified, that is, whether objections to Part XI will be accommodated and the Convention will enjoy both widespread and representative participation. This option will not last indefinitely.

In recent years, the laws and policies of many governments have been based on the assumption that in time the Convention would be widely ratified. Its entry into force puts that assumption to the test. If over time the assumption appears to be increasingly questionable, its influence as a restraining force on the laws and actions of governments may weaken. As states yield to the temptation to adopt measures inconsistent with the Convention, their willingness and political ability to ratify it will decline, and we will have lost a unique opportunity to reap its benefits.

The most significant impediments to ratification of the Convention by industrial states are legitimate objections to the deep seabed mining regime set forth in Part XI and related annexes. Serious negotiations to overcome those objections are now bearing fruit. New texts have been drafted that streamline and reduce the cost of the regime and institutions, increase the influence of industrial states over decisions, and replace controversial provisions, such as those dealing with finan-

\footnotetext{
${ }^{1}$ United Nations Convention on the Law of the Sea, opened for signature Dec. 10, 1982, UN Doc. A/CONF.62/122 (1982), reprinted in UNITED NATIONS, OfFicial TEXT OF THE UNITED NATIONS Convention on the LAW of the SEA WITH ANNEXes AND INDEX, UN Sales No. E.83.V.5 (1983) [hereinafter LOS Convention].

${ }^{2}$ Most of the first 60 states to ratify are in Africa, Asia and Latin America, including large countries such as Brazil, Egypt, Indonesia and Mexico.
} 
cial obligations, production limitations and transfer of technology, with marketoriented approaches. Recognizing that widespread ratification of the Convention would be encouraged by avoiding implementation of the objectionable provisions of Part XI when the Convention enters into force, the new texts facilitate the early implementation of the modified system and allow provisional participation for several years. The success of this effort is undoubtedly crucial to the fate of the Convention.

The political controversy over deep seabed mining has long captured the imagination of people who otherwise may have little interest in the oceans or the law of the sea, or international law for that matter. This has obscured a basic underlying fact. The Law of the Sea Convention deals with a large number of other issues of substantial importance to existing and reasonably foreseeable economic, environmental and security interests of states.

Misperceptions persist notwithstanding consistent efforts to set the record straight. ${ }^{3}$ The need to deal with these misperceptions, at a time when the future of the Convention hangs in the balance, inspires the authors to state views regarding its significance that are informed by their participation in its negotiation and related matters. ${ }^{4}$ Policy, not originality, is the object.

One sometimes wonders whether many of its critics have read the Convention. Some interested in economics and political economy opine about the acceptability of the Convention as if deep seabed mining were its sole object, and the ideology of the deep seabed mining regime an overriding priority. Elaborate theories about the conduct and utility of multilateral negotiations are derived from the failure of Part XI to bridge alternative perceptions in a generally acceptable manner. Many critics utter nary a word about important interests in energy, food, trade and communications, the environment or other matters successfully dealt with by the Convention.

Attempts to treat the Convention as a partisan issue in the United States ignore not only the facts about the Convention but its negotiating history as well. United States policy for a new convention on the law of the sea was first determined by President Nixon, taking into account a study commissioned by Congress, and was maintained in its essentials thereafter. Specific negotiating positions evolved in the course of the Nixon, Ford and Carter administrations in response to the views of other countries, as well as interested members of Congress, congressional staff

\footnotetext{
${ }^{3}$ Notable among these efforts is the work of the Panel on the Law of Ocean Uses, chaired by Professor Louis Henkin, whose papers include United States Interests in the Law of the Sea Convention, 88 AJIL 167 (1994); U.S. Interests and the United Nations Convention on the Law of the Sea, 21 OCEAN DEV. \& INT'L L. 373 (1990); Deep Seabed Mining and the 1982 Convention on the Law of the Sea, 82 AJIL 363 (1988); U.S. Policy on the Settlement of Disputes in the Law of the Sea, 81 AJIL 438 (1987); and Exchange Between Expert Panel and Reagan Administration Officials on Non-Seabed-Mining Provisions of LOS Treaty, 79 AJIL 151 (1985). Individual panel members and others have also written extensively on the issues involved.

* John R. Stevenson was Legal Adviser of the U.S. Department of State from 1969 to 1972 and Ambassador and Special Representative of the President to the Third UN Conference on the Law of the Sea from 1973 to 1975 . He has served as President and Honorary President of The American Society of International Law, and as a partner, and later Chairman and Senior Partner, of Sullivan \& Cromwell. Bernard H. Oxman served as attorney-adviser and Assistant Legal Adviser of the U.S. Department of State from 1969 to 1977 , was a member and later vice chairman of the U.S. delegation throughout the negotiation of the Law of the Sea Convention from 1969 to 1982, chaired the English Language Group of the Conference Drafting Committee, and now directs the Ocean and Coastal Law Program of the University of Miami School of Law.
} 
and the public. The Bush and Clinton administrations continued President Reagan's policy of respecting the Convention while maintaining objections to Part XI. Serious international efforts to find means to deal with the objections of industrialized states to Part XI were initiated by the UN Secretary-General during the Bush administration. Ill-informed attempts to portray interest in a successful Convention as some sort of left-wing conspiracy are also belied by the fact that most leaders of the U.S. delegation to the Law of the Sea Conference were Republicans.

Apart from a relatively narrow community of experts, few observers seem aware that President Reagan, while rejecting the deep seabed mining regime, embraced the remainder of the Convention dealing with traditional law of the sea issues and declared it to be the basis of United States policy. ${ }^{5}$ Indeed, careful scrutiny of his statements suggests that he was prepared to use force if necessary to defend certain rights guaranteed by a Convention that some of his supporters dismissed as utterly without virtue.

Even pragmatic business leaders could be misled by the misperception that the Convention is principally about deep seabed mining. Far more significant are substantive and dispute settlement provisions of the Convention that enhance the stability of expectations in the business of transporting oil and gas by sea, as well as extracting oil and gas from the continental shelf. The Convention is also important to the stability of expectations of investment bankers, insurance companies and others who underwrite and support shipping, offshore exploration and drilling, fishing and many other activities at sea. It would be a disservice to their stockholders for such businesses to formulate their views on ratification of the Convention on the basis of essentially speculative investments in consortia to recover deep seabed manganese nodules.

The same may be said of the duties of environmental leaders to their constituents. Some may have been misled into believing that this is a treaty about deep seabed mining that incidentally deals with some arcane issues of pollution from ships. Too few step back to observe that this is a strong, innovative and comprehensive global environmental treaty governing over two-thirds of the planet. With their support, it could be accepted as a binding treaty by the overwhelming majority of states. If ever there was an opportunity to demonstrate that environmental consciousness has fundamentally transformed international law, this is it.

The Convention lays down basic rules for the governance and protection of all of the sea, including the airspace above and the seabed and subsoil below. The deep seabeds are likely to remain the least used area addressed by the Convention. As defined in the Convention, the international seabed area (commonly referred to as the "deep seabeds") comprises that part of the seabed and subsoil that remains after formidable coastal appetites were satisfied by subjecting the resources of a 200-mile zone and the continental margin to coastal state jurisdiction. In particular, coastal states were able to ensure that virtually all geological structures associated with significant deposits of oil and gas are likely to be found within coastal state jurisdiction, not in the international seabed area.

Deep seabed mining has yet to occur. While promising sites have been identified by various companies that understandably wish to protect their investments, demand for the metals principally responsible for interest in manganese nodules,

\footnotetext{
${ }^{5}$ Statement by the President, Mar. 10, 1983, 19 WEEkLY COMP. Pres. Doc. 383 (Mar. 14, 1983), reprinted in 22 ILM 464 (1983).
} 
especially nickel and copper, has been depressed in recent years and may be satisfied for some time to come by sources on land. These metals can be stockpiled, and concerns have abated about the climate for remunerative investment in, and stable supply from, mines located in many countries of the world. In addition, hard minerals (whether in the form of nodules, polymetallic crusts or other deposits), geothermal energy and other resources also exist within the vast economic zones and continental shelves off the coasts of the United States and other states.

The provisions of the Convention dealing with activities on the deep seabeds other than mining are helpful. Navigation, telecommunications, scientific research and defense activities are protected. The potential use of the deep seabeds causing the most immediate and widespread environmental concern, namely disposal of wastes, is addressed within the framework of the Ocean Dumping Convention; ${ }^{6}$ both existing and future regulations under that treaty are incorporated by reference and strengthened by the substantive and dispute settlement provisions of the Law of the Sea Convention.

The important point is that the deep seabeds are only one part of the oceans and that deep seabed mining is only one interest addressed by the Convention. On the assumption that important objections to Part XI will be overcome by new texts, it is crucial to direct attention to the many other aspects of the Convention that have all too often been ignored or taken for granted, and to identify those benefits that are unlikely to be available at all, or to the same degree, in the absence of widespread ratification.

\section{STABILITY AND ORDERED CHANGE}

In most cases, the object of the Convention is to establish an agreed allocation of jurisdiction and concomitant duties among states, rather than to regulate activities as such. The rights and obligations of individuals and companies with respect to each other and to the public at large are the end products of the lawful exercise (or delegation) of jurisdiction by the appropriate state. Doubt or controversy about which activities are subject to the jurisdiction of which state impedes the elaboration and enforcement of national as well as international rules and standards governing specific uses of the sea. No right or duty is secure if it rests on an uncertain or contested jurisdictional foundation.

The history of the law of the sea in this century reveals a tendency to assume that a coastal state will benefit by unilaterally extending the monopoly control it enjoys on land to activities off its coast, without considering whether unilateral claims asserted by other states and instability in the law would be consistent with its interests. The Truman Proclamation stimulated (or at least was relied upon to justify) a cascade of claims by coastal states over the high seas that vastly exceeded the rights over the continental shelf claimed by the United States. The first two conferences on the law of the sea in 1958 and 1960 attempted to restore the stability of expectations that law should provide. Despite important accomplishments, however, no lasting accommodation was reached between the interests of states in controlling foreign activities off their own coasts and the interests of states in protecting the freedom to conduct activities off foreign coasts without interference.

\footnotetext{
"Convention on the Prevention of Marine Pollution by Dumping of Wastes and Other Matter, Dec. 29, 1972, 26 UST 2403, 1046 UNTS 120.
} 
History taught that war and conquest followed upon attempts to interfere with shipping or naval routes deemed vital by another state with the means to respond. Yet the trend toward claims that purported to expand coastal state control over navigation and overflight accelerated. That trend was manifested in expanding territorial sea claims, restrictive interpretations of the right of innocent passage within the territorial sea, and coastal state assertions of the right to impose unilateral restrictions on navigation beyond the territorial sea.

As a maritime power and trading nation with interests and responsibilities around the world, the United States would inevitably be sensitive to these problems. The cost of bilateral purchase of potentially important navigation rights in all the corners of the globe that U.S. trade or U.S. forces might wish to pass would be prohibitive. ${ }^{7}$ A situation was developing in which the United States would have to divert increasing resources, including naval and air forces, to confront foreign claims in order to protect the right to use areas of operational interest and to prevent the accumulation of adverse precedent; at the same time, the platform of principle for such resistance was collapsing as a result of accelerating foreign claims, as well as support for new coastal claims in Congress.

Similar problems confronted other states, including developing countries with limited means to protect the routes linking them to their friends and trading partners, and with less ability to absorb increased costs. Sophisticated observers recognized that nearly every coastal state needed an authoritative basis for reconciling its own long-term coastal and maritime interests and to maintain the integrity of that balance in the face of inevitable pressures to change it unilaterally. The goal was a stable accommodation of coastal and maritime interests both within and between coastal states that would be respected by each state's classe politique as a continuing restraint upon its jurisdictional choices.

There are four main reasons why a widely ratified Convention is a better guarantor of this long-term stability than customary international law.

First, governments are more inclined to respect obligations to which formal consent has been given by the highest political authorities. Even if the Convention is now generally declaratory of customary international law, this leaves much room for argument about important details.

Second, without widespread ratification, inevitable "violations" are more easily interpreted as evidence that state practice, the ultimate source of customary law, is not necessarily rooted in the Convention.

Third, the Convention contains compulsory dispute settlement procedures to help restrain unreasonable claims and contribute to a stable legal order. Customary international law imposes no such obligation and few states are under such an obligation to each other.

Fourth, the Convention contains a system for ordered change that strengthens rather than erodes the legitimacy of its basic structure. It is open to formal amendment and encourages supplementary agreements and organizational arrangements with the participation of affected states. Its interpretation will be adapted to changing circumstances by authoritative tribunals. It incorporates by reference future safety and environmental rules, and contains a flexible system of shared competence for regulating navigation in particularly sensitive or dangèous coastal areas.

\footnotetext{
${ }^{7}$ A reciprocal grant of similar rights off the United States coast would rarely be regarded as adequate "consideration" in such arrangements. Geography alone determines that few foreign states need to navigate past the U.S. coast to reach destinations outside the United States.
} 
The traditional method for adapting the customary international law of the sea to new circumstances and special problems has been unilateral claims of jurisdiction by the coastal state, the very source of instability in the law of the sea in the past.

\section{INTERNATIONAL SECURITY, TRADE AND COMMUNICATIONS}

Since the dawn of history, the sea has served humanity as a primary avenue of communication, whether by ship, aircraft or cable.

From the perspective of international security, the basic question is whether forces may be moved from one place to another without the consent or interference of states past whose coasts they proceed. Global mobility is important not only to naval powers but to other states that rely on those powers to maintain stability and deter aggression, directly or through the United Nations. As the size of major navies is reduced after the Cold War, the adverse impact on their ability to perform their primary missions will increase if they must divert scarce resources to challenging coastal state claims that prejudice global lines of communication or set adverse precedents. Enhancing the legal security of navigation and defense activities at sea maximizes the efficient use of defense resources.

From the perspective of trade and communications, the basic question is whether two states may communicate with each other by sea without interference by a third state past whose coast they proceed. Restrictions imposed by a coastal state along the route may well result in increased costs for industries dependent upon trade and communications and for countries whose exports or imports are affected.

If governments accorded unquestioned priority to interests in international security, trade and communications, there would be no law of the sea problem with respect to coastal state claims. In earlier centuries when the freedom of the. seas reigned supreme, the law of the sea was relatively stable. Decolonization, technological development and environmental sensitivity altered priorities in the twentieth century. It is no longer plausible to insist upon global mobility as the sole interest informing policies regarding coastal state jurisdiction. One cannot have a stable law of the sea that protects navigation and communications unless one finds a way to accommodate coastal state interests in controlling economic development of vast offshore areas and protecting the coastal environment.

The Convention seeks to reconcile the conflicting pressures with a complex allocation of rights and duties. It limits the breadth of the territorial sea to 12 nautical miles, guarantees free transit for all ships and aircraft through straits overlapped by the territorial sea and through archipelagos, and preserves freedom of navigation, overflight, laying of cables and pipelines, and related uses seaward of the territorial sea. At the same time, it gives the coastal state jurisdiction over living and nonliving resources, drilling, marine scientific research, and most installations and structures in an exclusive economic zone extending up to 200 miles from the coast and, on the seabed, beyond 200 miles to the outer edge of the continental margin. ${ }^{8}$ It establishes detailed coastal state rights and duties to adopt and enforce antipollution standards in these areas.

The Convention offers three protections from the risk that this system will gradually evolve into the functional equivalent of a 200-mile territorial sea under

\footnotetext{
*It also doubles, to 24 miles from the coast, the breadth of the contiguous zone in which smuggling and immigration laws may be enforced.
} 
discretionary coastal state control, effectively territorializing all of the major seas of the world. First, the rights and duties of coastal states and flag states are carefully enumerated. For example, there are requirements for prompt release on bond of foreign ships arrested for pollution or fisheries violations, and protections for their crews. Second, the regulation of navigation is closely tied to rules adopted or approved by the competent international organization, presumably the International Maritime Organization. Third, both the coastal state and the flag state are subject to compulsory arbitration or adjudication with respect to navigation, overflight and related rights. This includes a rapid system for ordering the release on bond of ships arrested by the coastal state.

These protections are dependent upon or strengthened by widespread ratification of the Convention. Compulsory dispute settlement is especially likely to be the key to ensuring that the complex balance between coastal state jurisdiction and the freedoms of navigation and communication is respected and evolves in an orderly way. It may well be a useful tool for governments in their attempts to restrain their own political processes. It is also an important option for responding peacefully, but effectively, tó excessive coastal state claims or interpretations.

\section{Protection of the MARINe ENVIRONMENT}

The advance in international environmental law effected by the Convention is reflected in the unfettered clarity of the opening article of Part XII: "States have the obligation to protect and preserve the marine environment."9

The Convention requires states to ensure that activities under their jurisdiction do not cause environmental damage to other states or result in the spread of pollution beyond their own offshore zones; to minimize to the fullest possible extent the release of harmful substances into the marine environment from landbased sources; to protect rare or fragile ecosystems; to conserve living resources; and to prevent the introduction of alien species into the marine environment where they may cause harm. It also provides for environmental impact assessments of planned activities, environmental monitoring of ongoing activities, and contingency planning for pollution emergencies. States are required to cooperate in establishing global and regional rules and standards for specific sources of pollution.

The environmental obligations placed on states relate to activities subject to their jurisdiction. Taken as a whole, the Convention therefore clarifies not only the nature of the environmental obligations of states, but also the activities and areas that are the object of those obligations. Four factors are particularly important in assessing the significance of this effort to combine the allocation of economic and other rights with the assumption of environmental duties.

First, the environmental regime is incorporated into a binding treaty. While a growing number of global and regional treaties deal with important environmental matters, none purports to impose comprehensive environmental obligations on so many activities in so many places. Other comprehensive global environmental instruments, including those adopted at Stockholm in 1972 and Rio de Janeiro in 1992, have been nonbinding declarations. Enthusiasts may rush to pronounce such instruments declaratory of customary international law, but even they presumably understand that this is not the same thing as an international commit-

\footnotetext{
${ }^{9}$ LOS Convention, Art. 192. Experienced international negotiators are well aware of the difficulty of achieving agreement to articulate an environmental norm in such direct and unqualified form.
} 
ment accepted as binding by the highest political organs of a state, including its parliament, especially when it comes to making the hard political choices necessary to implement environmental standards.

Second, because it contains other incentives for ratification, the Convention enjoys reasonable prospects of becoming perhaps the most widely ratified environmental treaty. That goal is virtually assured if ratification is forthcoming from states in which environmental objectives are accorded high priority.

Third, in addition to establishing the basic environmental jurisdiction and duties of states, the Convention obliges the parties to adopt and enforce pollution control regulations with respect to particular sources, notably ships, ${ }^{10}$ ocean dumping, oil drilling and offshore installations. It provides that these regulations shall at least have the same effect as, or be no less effective than, international rules and standards that emerge from the work of competent international organizations now and in the future, presumably with widespread and representative support. This duty applies to all parties to the Convention, whether or not they are otherwise bound to apply a particular standard.

Lastly, compliance with environmental standards under the Convention is subject to compulsory arbitration or adjudication. While compromissory clauses are not unknown in marine pollution treaties, the coupling of compulsory arbitration and adjudication with environmental obligations under this Convention is an extraordinary advance over past practice.

Every coastal state shares both the communications and environmental interests that require harmonization in the allocation of rights and duties to regulate pollution from ships. Both ships and contaminants move at sea. No coastal state can protect its environmental interests adequately unless it achieves agreement from other states to apply restraints to ships under their control. Similarly, no state can protect its communications interests unless it achieves agreement from many coastal states regarding the appropriate balance between freedom of navigation and coastal state competence to interfere with that freedom for environmental reasons.

The result is one of the most complex efforts at harmonization contained in the Convention. Specific prescriptive and enforcement powers over foreign ships are conferred on coastal states by the Convention but are subject to important limitations and safeguards to protect against coastal state excesses. The entire system is subject to compulsory arbitration or adjudication to help ensure respect for both environmental duties and navigational rights and to safeguard the stability of this complex balance. ${ }^{11}$

Naturally enough, there are those who would have liked the Convention to do more. For example, they might have preferred a more strongly worded duty to enforce international standards to control land-based sources of marine pollution. One difficulty was that delegates to a conference on the law of the sea had

\footnotetext{
1" Following the pattern of other marine pollution treaties, the environmental provisions of the Convention do not apply to warships and other government noncommercial ships and aircraft, but each state is required to ensure that its excluded vessels and aircraft act in a manner consistent with those provisions so far as is reasonable and practicable.

"Two significant exceptions to compulsory arbitration or adjudication under the Convention are "disputes concerning military activities" and disputes "with regard to the exercise by a coastal State of its sovereign rights or jurisdiction." The latter exception does not apply to coastal state violation of navigation rights and freedoms or specified environmental rules and standards. LOS Convention, Art. 297, para. 1, Art. 298, para. 1(b).
} 
doubts about their competence to deal with activities on land that might cause marine pollution. Delegates to the 1992 Rio Conference, who suffered from no such disability, witnessed the difficulty of getting states to agree to binding rules affecting significant activities on land. Negotiations are continuing in environmental forums where specific land-based sources of marine pollution are being targeted.

The Convention is the strongest comprehensive environmental treaty now in existence or likely to emerge for quite some time. It is wishful thinking to believe that the Convention will have as much impact if it is not widely ratified. Nonparties may be particularly unwilling to regard themselves as bound by the environmental duties outlined in the Convention if governments and organizations ordinarily sensitive to environmental issues fail to work for widespread ratification. The message inherent in such behavior is likely to drown out protests to the contrary.

\section{Coastal Resources}

The alacrity with which coastal states "implemented" the sovereign rights elaborated in the Convention with respect to oil and gas, fisheries, and other natural resources of the economic zone and continental shelf suggests that widespread ratification of the Convention would not make a significant difference with respect to coastal resources. That is not entirely true, even if one has faith that coastal state rights are as safely consolidated by customary international law as by a widely ratified Convention. For example, the economic benefits of exporting such natural resources may well depend on respect by other states for navigational rights and for a balanced allocation of competence to control pollution from ships. Widespread ratification of the Convention is more likely to promote such respect.

\section{Oil and Gas}

One of the reasons coastal state jurisdiction over the continental shelf was extended to the edge of the continental margin was to incorporate potential hydrocarbon deposits in the continental rise. Oil and gas development requires substantial site-specific investments. The Convention protects both the coastal state and the investor from future disputes about the location of the seaward limit of coastal state jurisdiction over the continental margin. Limits established by the coastal state on the basis of the recommendations of an international commission of experts to which supporting data have been submitted are final and binding on all parties to the Convention and the International Sea-Bed Authority.

The extension of coastal state jurisdiction over the continental margin, and the consequent exclusion of the hydrocarbon potential of the continental rise from the international seabed area, was balanced by the provision for a modest sharing of revenues from the continental margin beyond 200 miles. ${ }^{12}$ This system not only affords benefits to developing countries (including landlocked countries), but creates a global interest in the legitimacy and exercise of coastal state jurisdiction over the continental margin, notwithstanding the disproportionate benefits conferred on certain large and prosperous coastal states.

\footnotetext{
${ }^{12}$ These provisions are what remain of a more ambitious proposal for revenue sharing by President Nixon in 1970.
} 
Seaward extension of the limits of the continental shelf and expansion of the type of installations subject to coastal state jurisdiction also raised doubts about the rigidity of the 1958 Convention on the Continental Shelf with respect to the size of safety zones around offshore installations and the requirement that installations must be entirely removed once they are no longer in use. Those rules were designed to ensure respect for other uses of the marine environment, both spatially and temporally. If the rules were to be made more flexible, means would have to be found to ensure that interests in other uses and protection of the marine environment were adequately reflected (including interests in the safe and expeditious transport of hydrocarbons by ship). The Convention achieves this by delegating to the competent international organization, presumably the International Maritime Organization, the authority to establish guidelines for deviating from the strict requirements regarding safety zones and removal of installations.

Accidents and pollution in one part of the world may increase resistance to oil and gas development elsewhere. In addition to their environmental interests, both coastal states and investors have a significant economic interest in assuring that every coastal state takes adequate measures to protect against pollution from offshore hydrocarbon development. The Convention accommodates this interest by providing that all coastal states must at a minimum respect international environmental standards established by the competent international organization.

\section{Fisheries}

One of the most significant threats to marine life is pollution of the marine environment. That pollution originates in many ways and in many places. No state is in a position to solve the problem alone, even off its own coast. Widespread ratification of the Convention is likely to promote greater protection from pollution. For that reason alone, those concerned about living resources should support ratification.

The biological boundaries respected by most stocks of fish in the wild have little in common with the political boundaries drawn by states. What is required is consistent management of ecosystems and fish stocks throughout their migratory range. No general convention can achieve that. But the Convention at least makes clear that economic zones are not the end of the inquiry, and that sound management is required on the basis of biological characteristics. ${ }^{13}$

Unless management is coordinated, fishing outside a state's zone can prejudice both its conservation measures and the economic preferences accorded its fishermen within the zone. The 1992 Rio Conference called for international negotiations on the matter, which are now under way. The future of the Convention, and the stability of the law of the sea, may depend on the willingness of governments to negotiate constructively in this regard.

General legal rules must be applied to specific regions in any event. In some regions it may be easier to resolve the problem directly by agreement among the states concerned with fishing in that area. Such an agreement was recently nego-

\footnotetext{
${ }^{13}$ This includes conservation measures that take into account the interdependence of species, optimum utilization, coordination between neighboring coastal states, special rules for species that migrate between fresh water and the open sea, cooperation in managing highly migratory species, and agreement with the coastal state on measures to conserve stocks that migrate between the economic zone and the waters seaward of the zone. Marine mammals are afforded special protection, including exemption from requirements for optimum utilization.
} 
tiated with respect to the so-called doughnut hole that is completely surrounded by the economic zones of Russia and the United States in the Bering Sea.

It should nevertheless be borne in mind that widespread ratification of the Convention could help. The Convention expressly makes the right to fish beyond the economic zone subject to the rights, duties and interests of the coastal state provided for in connection with the economic zone. Fishing beyond the economic zone is subject to compulsory arbitration or adjudication. Tribunals are empowered to prescribe provisional measures "to preserve the respective rights of the parties to the dispute or to prevent serious harm to the marine environment, pending the final decision." Should resort to Convention procedures fail to yield compliance, there is established doctrine regarding the right of a state to respond to violations of a treaty by another party without challenging the integrity or binding force of the treaty as such.

This approach should be contrasted with the momentous consequences for the future of the Convention and the law of the sea if states that have yet to ratify the Convention were now to make new unilateral claims over the waters beyond the economic zone. ${ }^{14}$ They would bear a heavy burden were they to destroy the practical opportunity the world now has to accept an agreed framework governing all the uses of all the oceans.

\section{MARINE ScIENTIFIC Research}

Many coastal states believe they should have jurisdiction over marine scientific research wherever they have jurisdiction over exploration and exploitation of natural resources. Freedom of scientific research is therefore a likely, if not inevitable, victim of extensions of coastal state jurisdiction over resources as a result of either unilateral claims or negotiations. This suggests that, from the perspective of marine scientific research, widespread ratification of the Convention makes little difference. That conclusion is not quite correct.

The Convention contains detailed procedures and criteria for obtaining coastal state consent to conduct scientific research in the economic zone and on the continental shelf, and provides that coastal states shall, in normal circumstances, grant their consent unless the research comes within enumerated exceptions. An "implied consent" rule promotes timely response by coastal states. The Convention also narrows the grounds for withholding consent for scientific research on the continental margin seaward of 200 miles where there is no ongoing resource development activity.

There are a number of other useful provisions. Marine scientific research must be respected in the course of other activities at sea. The Convention encourages publication or dissemination of research results. It confirms the right to conduct scientific research on the high seas beyond the economic zone and in the international seabed area, protects that right with compulsory arbitration or adjudication, and stabilizes the limits of those areas.

\footnotetext{
${ }^{14}$ Chile recently declared a "mar presencial" of uncertain content. The effect of Argentine legislation is also unclear. Canada is under pressure from Newfoundland fishermen to reduce foreign fishing beyond the economic zone, and Prime Minister Chrétien alluded to the possibility of a unilateral claim during his election campaign.
} 


\section{CONCLUSION}

All previous efforts in this century to bring the world together in a stable agreement on an international regime for the oceans failed. The UN Convention on the Law of the Sea is the closest we have come. The goal is now within reach.

The Convention was caught in the crossfire of ideological wars that are now behind us. Remarkably, those wars never really affected more than one part of the Convention, namely Part XI. That damage is now being repaired by the negotiation of significant changes designed to accommodate objections to the deep seabed mining regime.

The ideological wars of the past also perpetrated incomplete and ill-informed perceptions about the Convention that impede rational analysis. The authors are confident that at least the large majority of those who make the effort to study the Convention as a whole, and consider the alternatives, will agree that widespread ratification is important and that the opportunity we now enjoy to achieve that goal should not be allowed to pass us by.

For those with a sense of history and perspective, the significance of a widely ratified Convention on the Law of the Sea transcends even the oceans. Since the time of Grotius, the law of the sea has been a significant part of the fabric of modern international law. If we can succeed in strengthening the international law of the sea with a widely ratified Convention, we will strengthen the fabric of international law generally.

One of the weaknesses of international law is that states have been reluctant to accept the jurisdiction of courts and arbitrators in principle. At least with respect to many issues of international law that arise in connection with the oceans, a widely ratified Convention on the Law of the Sea would remedy that weakness in a fundamental way. No comparable treaty with such broad mandatory compromissory clauses has ever been widely ratified. Progressive written articulations of the law by authoritative tribunals are by no means the same thing as self-help rooted in unilateral perceptions of the potential for forcing acquiescence. And it is the latter that has often passed for the law of the sea in this century.

A widely ratified Convention, including new texts that accommodate objections to the deep seabed mining regime, would be a monument to the possibilities of global multilateral diplomacy. Such a success could be particularly important at a time when states are beginning to shape a post-Cold War international order. It would demonstrate that, with time and care, consensus can be achieved on reconciling important security, economic, environmental and other interests; that this consensus can be expressed in reasonably precise norms and rules that narrow the issues and limit disputes; and that parliaments can be persuaded to embrace the result in the common interest.

From the broadest perspective, widespread ratification should be especially significant for governments that attach particular importance to their capacity to influence international affairs by their participation in international negotiations and institutions, and for those of us who prefer a public order in which inclusion and rational dialogue are the foundations of policy.

JoHn R. STEVENSON AND BERNARD H. OXMAN 